\title{
VIEWPOINT
}

\section{Artists in the Streets. Seattle Murals in the Time of COVID-19}

\author{
Catherine Anstett \\ Seattle, United States of America \\ dcasea2@hotmail.com
}

\begin{abstract}
Seattle has become known in recent years as the city with the most construction cranes in the nation. But in March 2020, the city grew quiet. The Seattle area was one of the first in the United States to be hit with the coronavirus and on March 16 Governor Jay Inslee closed restaurant dining rooms state-wide. On March 23, he issued a stay-athome order. Stores and restaurants closed; streets and sidewalks became empty. Property crime went down in residential areas because people were at home, but businesses and storefronts became targets. In some areas, windows were covered with plywood as a security measure.

Artists began to paint the shuttered storefronts and then one after other businesses requested the murals. Business groups in several communities sponsored murals and offered stipends to artists, prioritizing artists from the local neighbourhood. These neighbourhood streets became outdoor museums. By early May, there were nearly 200 murals.

A virtual community formed as artists, photographers and friends shared videos and photos on social media. AP and Reuters photographers posted images that reached as far as Mumbai. The Seattle Office for Arts and Culture said, "Throughout this crisis, we have seen community come together and hold each other up like never before. We have watched organic movements take hold that are devoted to supporting those in need financially, emotionally, spiritually, and creatively." The murals were an important part of this effort, for the artists, businesses, and the larger community. A book documenting the murals was published.

As Seattle artist B Line Dot said, "Art marks moments... this is a moment."
\end{abstract}

Keywords: murals, COVID-19, Seattle, Capitol Hill

To cite this article:

Anstett, C. (2020). Artists in the Streets. Seattle Murals in the Time of COVID-19, The Journal of Public Space, 5(3), 255-266, DOI 10.3289I/jps.v5i3.14I4

This article has been double blind peer reviewed and accepted for publication in The Journal of Public Space. (C) This work is licensed under a Creative Commons Attribution - Non Commercial 4.0 International License https://creativecommons.org/licenses/by-nc/4.0/ 


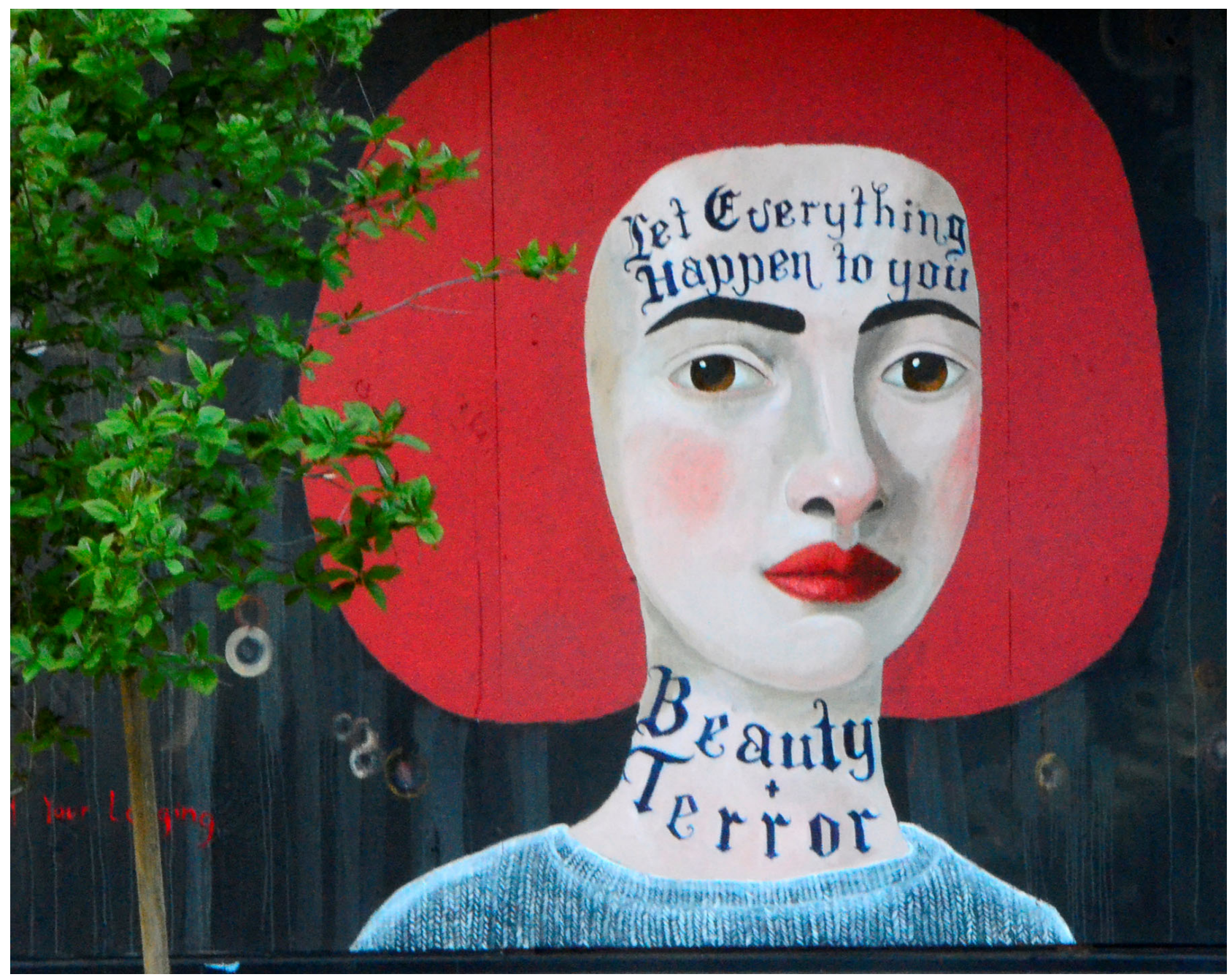

Figure I. A mural by Anne Siems, titled 'Beauty + Terror', on a boarded building in Seattle's Capitol Hill neighbourhood. The (red) quote on the left says: 'Go to the Limits of your Longing' poem by Ranier Maria Rilke. Picture by Catherine Anstett (2020).

Seattle has become known in recent years as the city with the most construction cranes in the nation.' But in March 2020, the city grew quiet. The Seattle area was one of the first in the United States to be hit with the coronavirus and on March 16 Governor Jay Inslee closed restaurant dining rooms statewide. On March 23, he issued a stay-at-home order. Stores and restaurants closed; streets and sidewalks became empty. Property crime went down in residential areas because people were at home, but businesses and storefronts became targets. In some areas, windows were covered with plywood as a security measure. (Figures a,b)

In March, the Jade Garden Restaurant in Seattle's Chinatown/International District was broken into, and the restaurant boarded its windows with plywood. It was never certain whether this was a hate crime related to the virus. The community responded, as local photograph Keiko Silvano sought artists to paint the plywood, in part to attract customers since the restaurant was still open for takeout and delivery. Five Latino artists volunteered and painted murals to reflect the spirit of the restaurant (Figures c,d,e). 

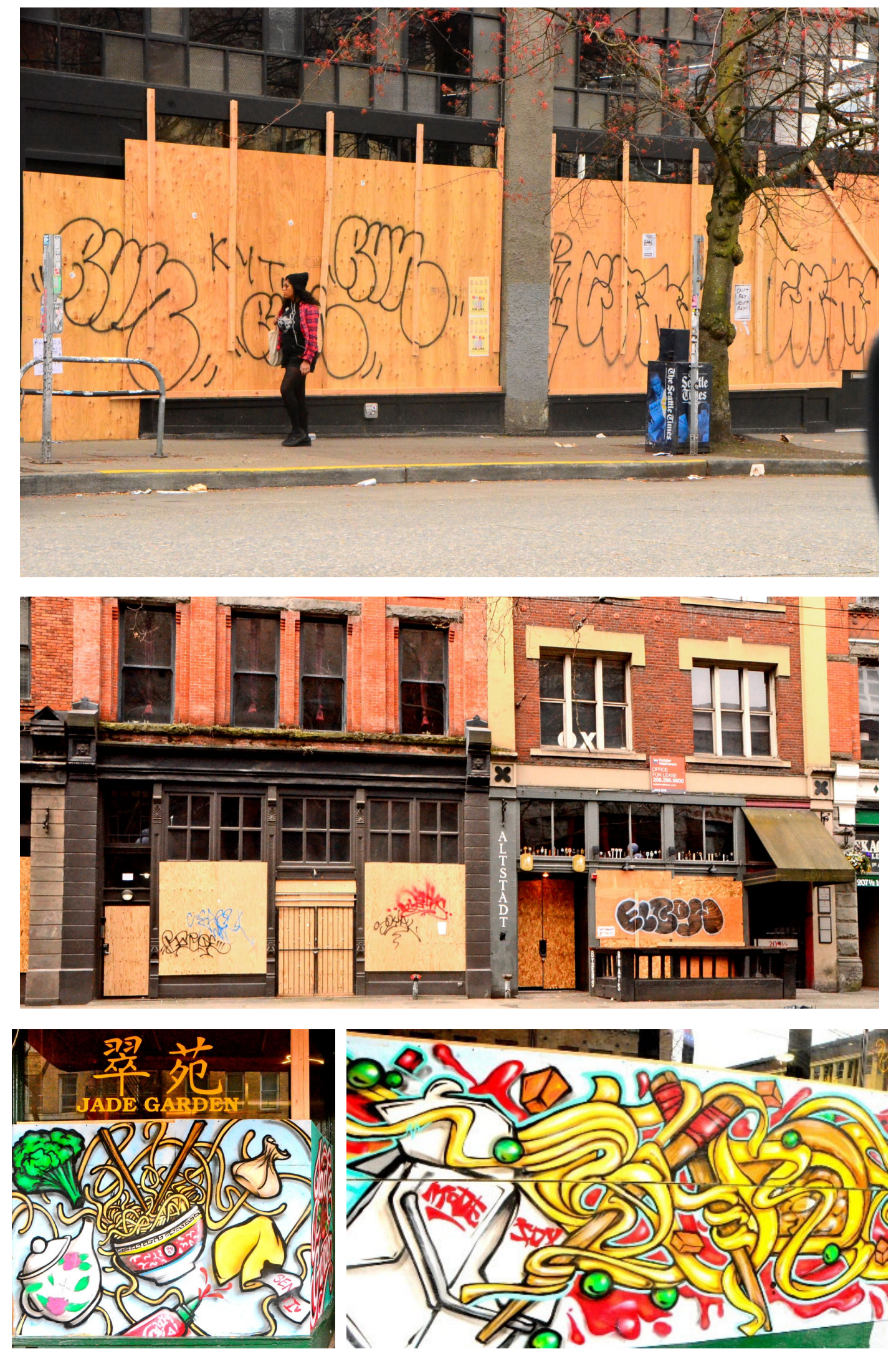

Figure a, b, c, d, by Catherine Anstett (2020). 

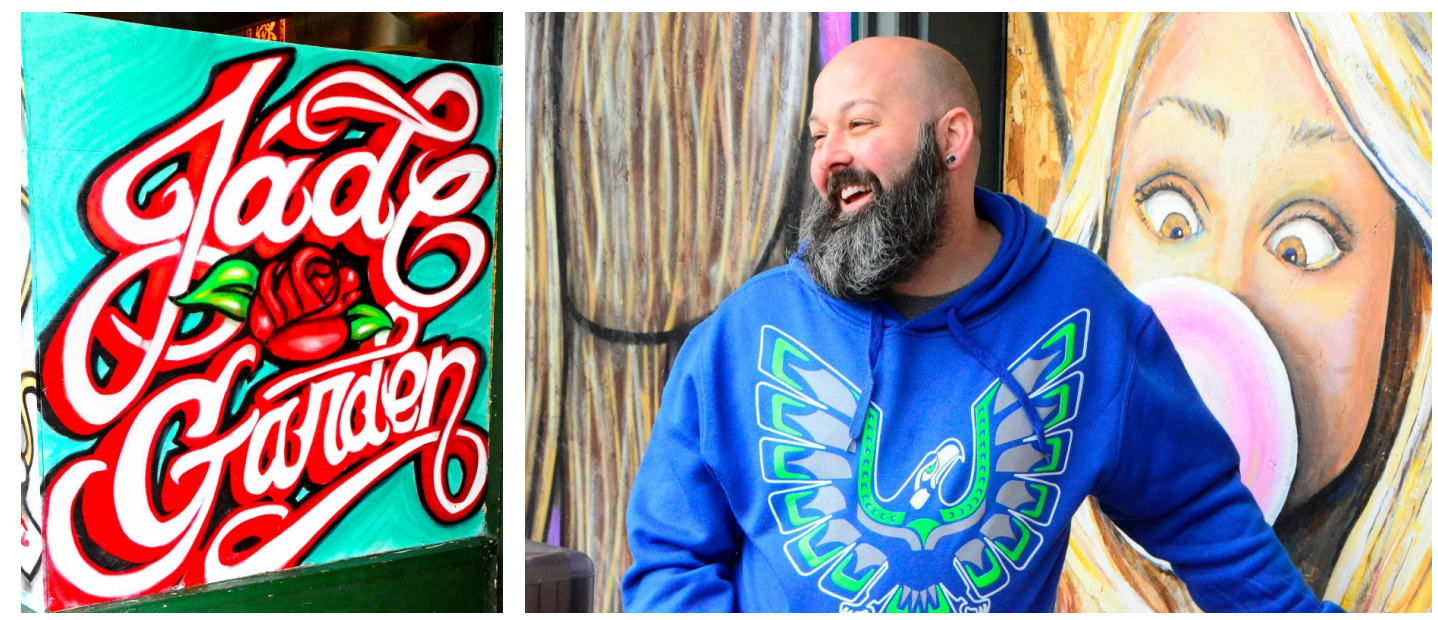

Figure e (left), Figure $f$ (right), background murals are by Henry and by Debora Spencer. Picture e and f by Catherine Anstett (2020).

In a nearby neighbourhood, Belltown Pizza was vandalized and owner Brian Lee put out a call on Facebook to artists. Within hours he had more than 200 responses and became the point person for murals not just on his restaurant but in the Belltown neighbourhood (Figures f,g,h). Some Capitol Hill bars had their windows broken by an axe wielding vandal. Artists began to paint the shuttered storefronts and then one after other businesses requested the murals (Figures i,j).

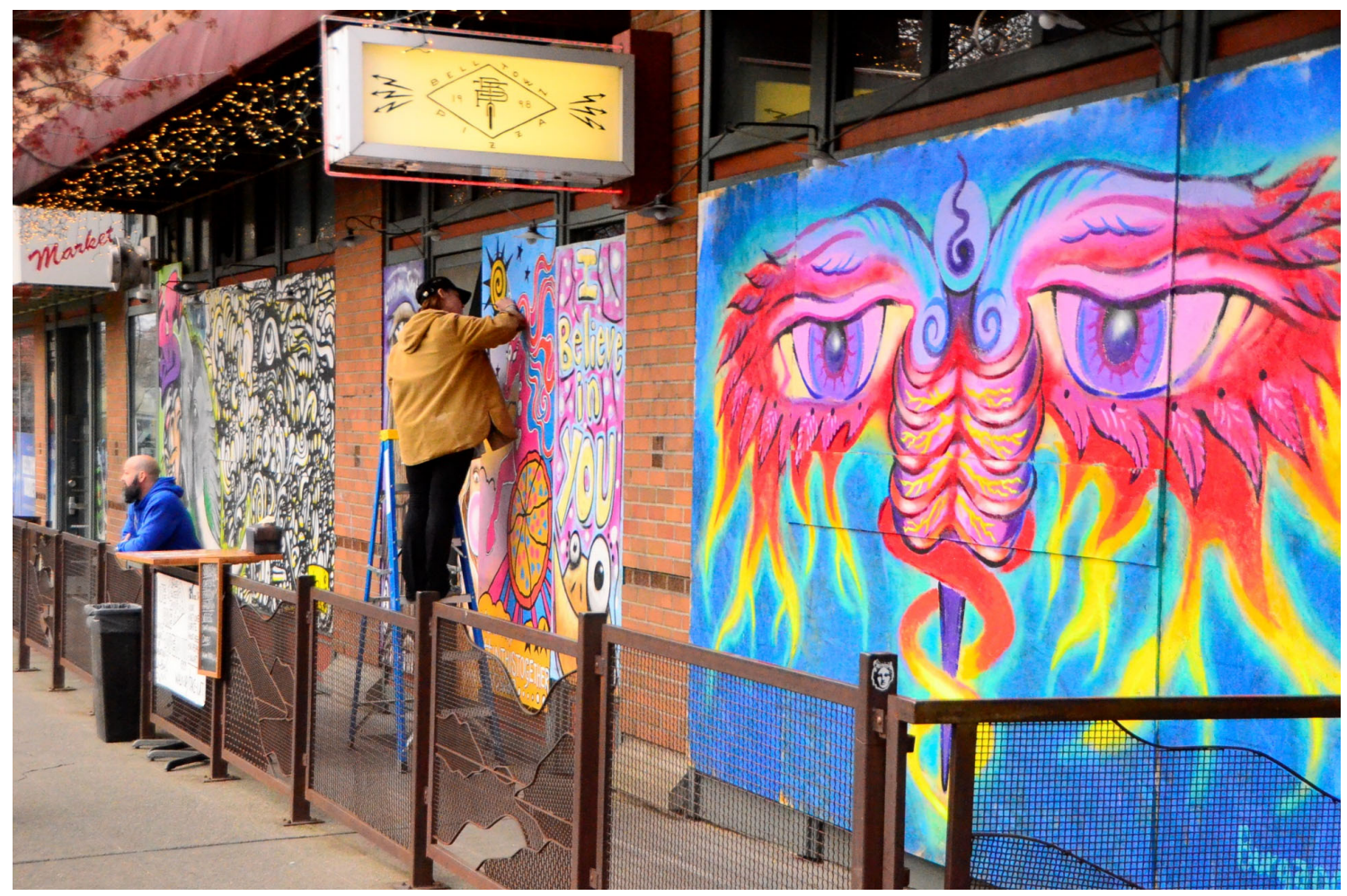

Figure g. Artist Tara Velan and Burgandy Viscosi. Picture by Catherine Anstett (2020). 
Artists in the Streets. Seattle Murals in the Time of COVID-19

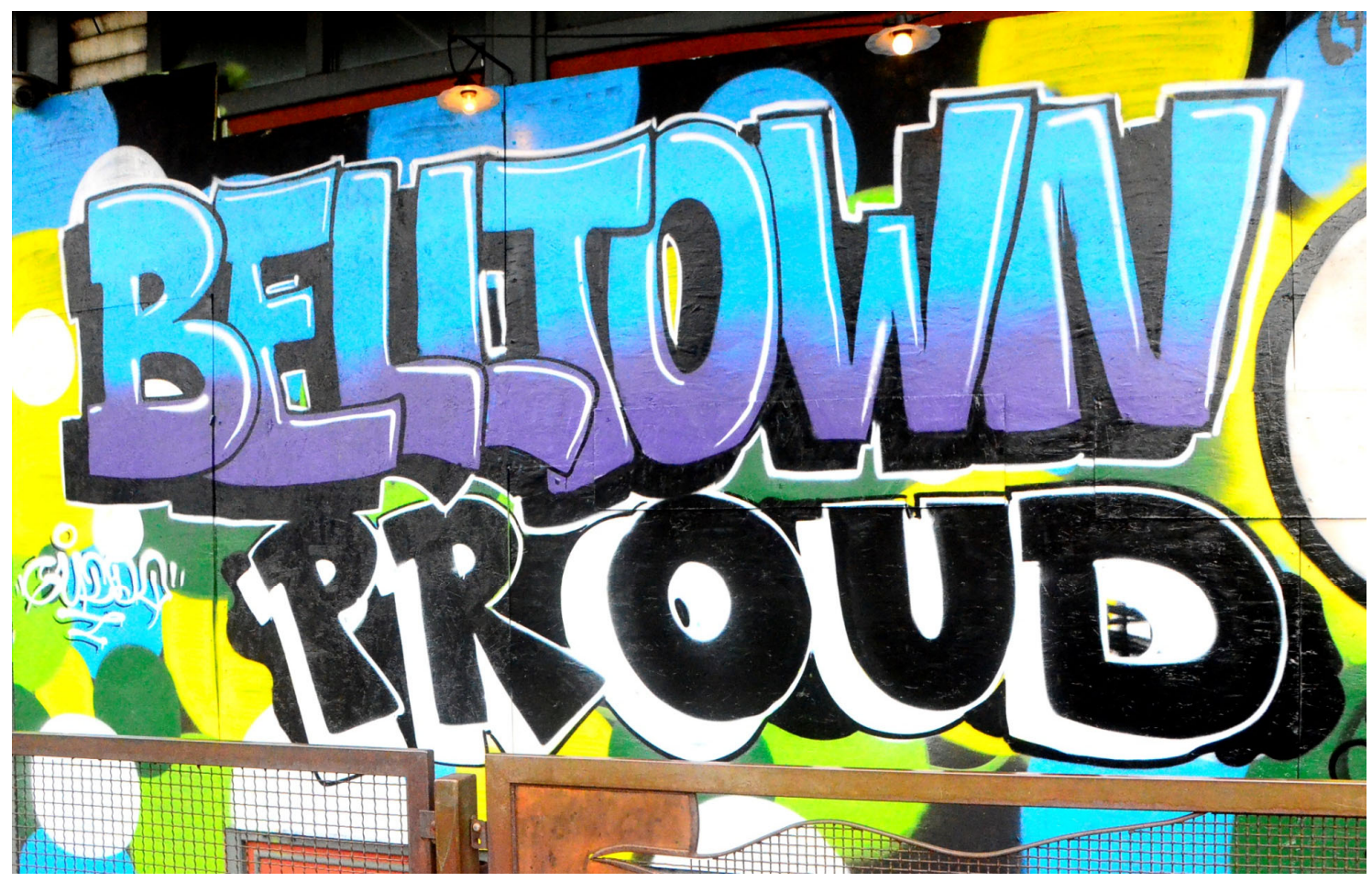

Figure h. Artist Antonio Varchetta. Picture by Catherine Anstett (2020).

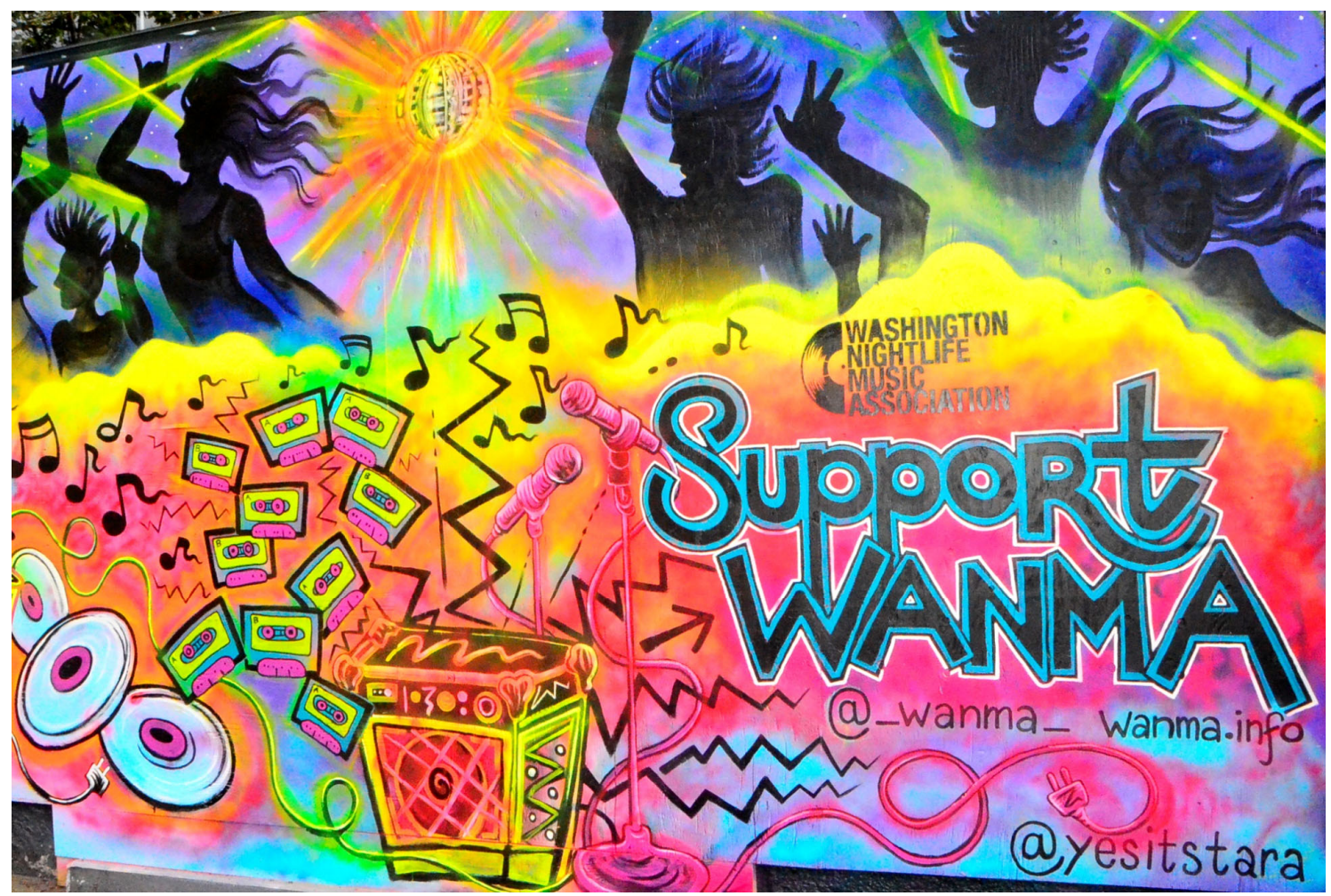

Figure i. Artist Tara Velan. Picture by Catherine Anstett (2020). 


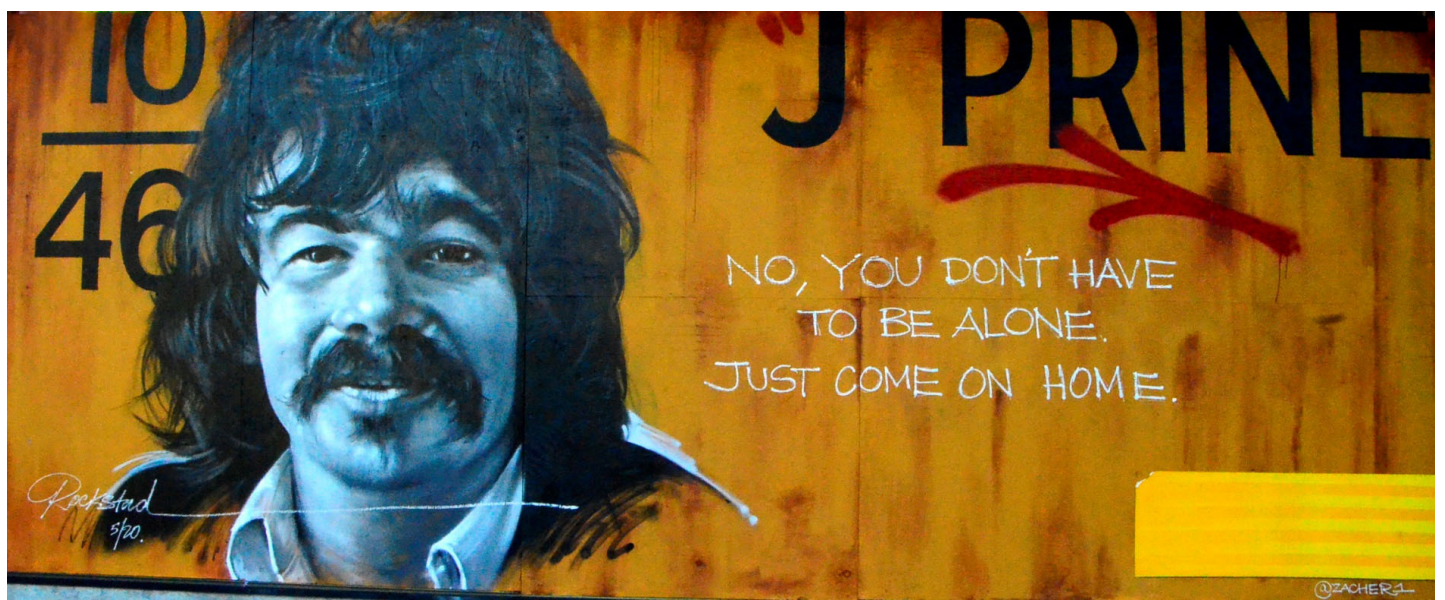

Figure j. Artist Zach Rockstad. Picture by Catherine Anstett (2020).

Business groups in several communities sponsored murals and offered stipends to artists, prioritizing artists from the local neighbourhood. Some of the murals coordinated through the Ballard Alliance reflect that community's Scandinavian heritage. The Alliance for Pioneer Square initiated a mural program, and there are now more than 40 murals in this historic neighbourhood. The Alliance has created an interactive map detailing the murals. (Figures $k, l, m, n$ )

These neighbourhood streets became outdoor museums. By early May, there were nearly 200 murals. You could watch the artists as they created their works and talk to them as they painted. In some cases it was practically performance art. The unpredictability of where the next mural would appear made it even more entertaining. (Figures o,p,q)
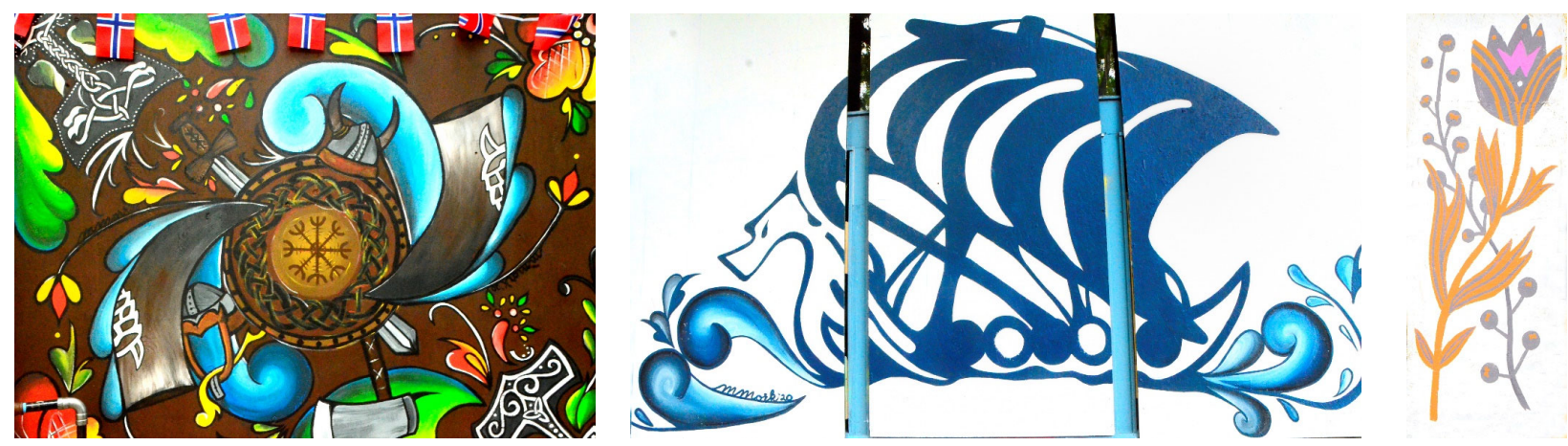

(Left to right) Figure k. Marit Helena Mork.

Figure I. Artist Marit Helena Mork. Figure m. Artist Tori Shao.

Pictures by Catherine Anstett (2020).

The artists ranged from street artists, who did not want their names or faces to be shown. to studio artists who had never done a large-scale painting. There were impressionist freehand artists and meticulous sign painters. Many of the artists had admired each other's work, but never met before. Jay Mason posted: "It has been so rad and inspiring to be working next to amazing artists such as Joseph Nix on the left and Japhee on the right. It has been amazing to watch and learn from two masters of our time." 2 


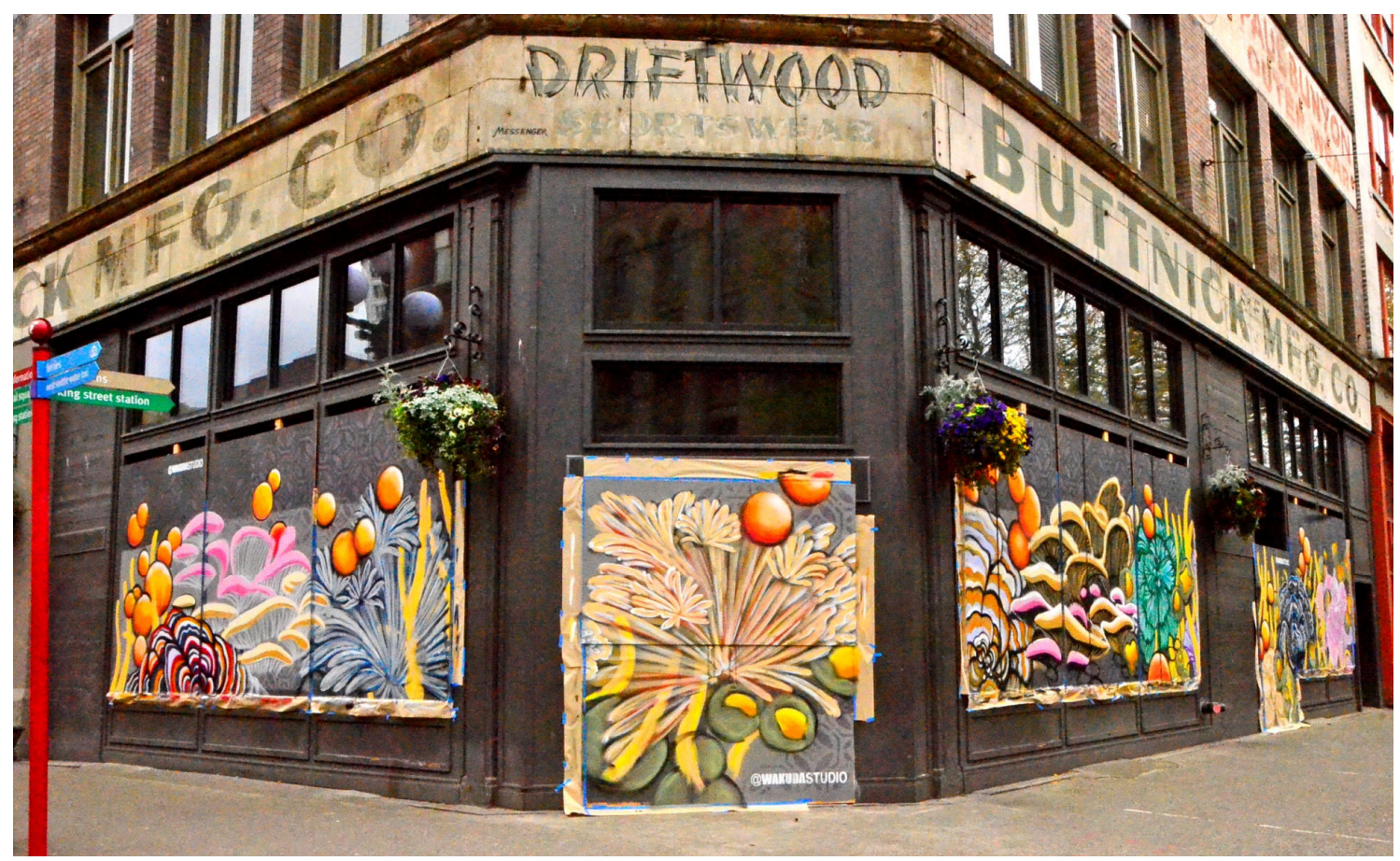

Figure n. Artists Jonathan Fischer and Wakuda Studio. Picture by Catherine Anstett (2020).

The muralists often worked as teams, while safe-distancing. The Overall Creative team inventoried the supplies they had on hand and could share with each other. With those materials and a bucket of black paint they did ten initial murals in the Capitol Hill neighbourhood (Figures r,s,t).
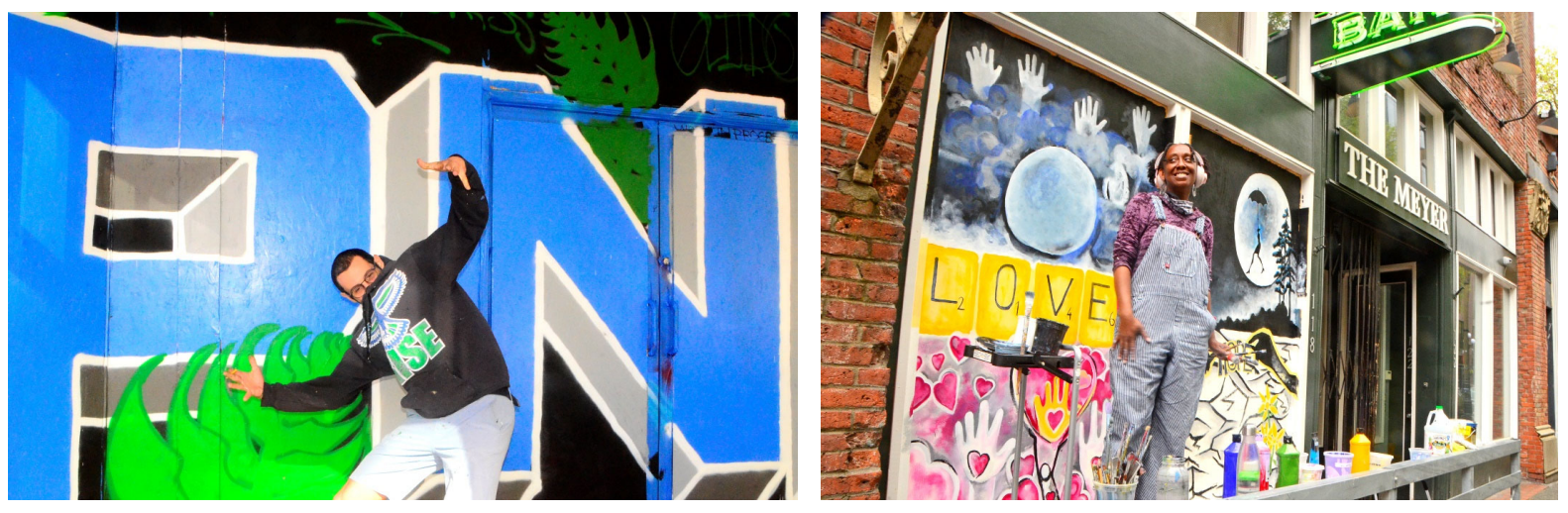

(left to right) Figure o. Artist Antonio Varchetta. Figure p. Artist Carol Rashawnna Williams. Pictures by Catherine Anstett (2020).

A virtual community also formed as artists, photographers and friends shared videos and photos on social media. AP and Reuters photographers posted images that reached as far as Mumbai.

The murals ranged from frivolous and fun to political and inspirational (Figures $u, v, w, x, y, z$ ). B Line Dot described his “Keep Dreaming” mural: "This message to keep dreaming is for all of us who feel stagnant and stifled by the current events... it is unprecedented and historic but what we do with it and beyond it will define us... so please keep dreaming, 
keep hoping and above all else keep loving... we need each other more now than ever."3 (Figure za)

A recurring theme was astronauts. Sam Trout said of his mural "I'LL SEE YOU...WHEN WE LAND," that it "stems from the idea that we're all astronauts in training right now. Lots of isolation, communication through video screens, a little space madness, and we'll land on a planet much different from the one we left." ${ }^{4}$ (Figure zb,zc)
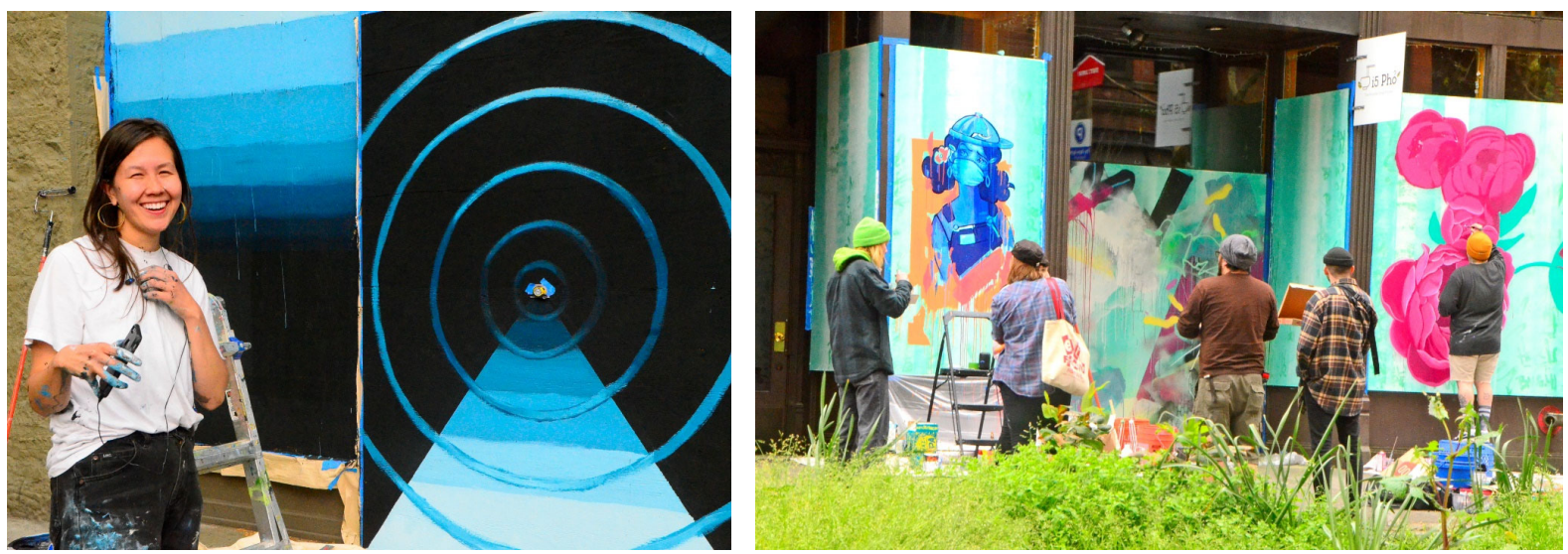

(left to right) Figure q. Artist Mari Shibuya. Figure r. Artists Madeline Owen and Jay Michael B Line Dot. Pictures by Catherine Anstett (2020).
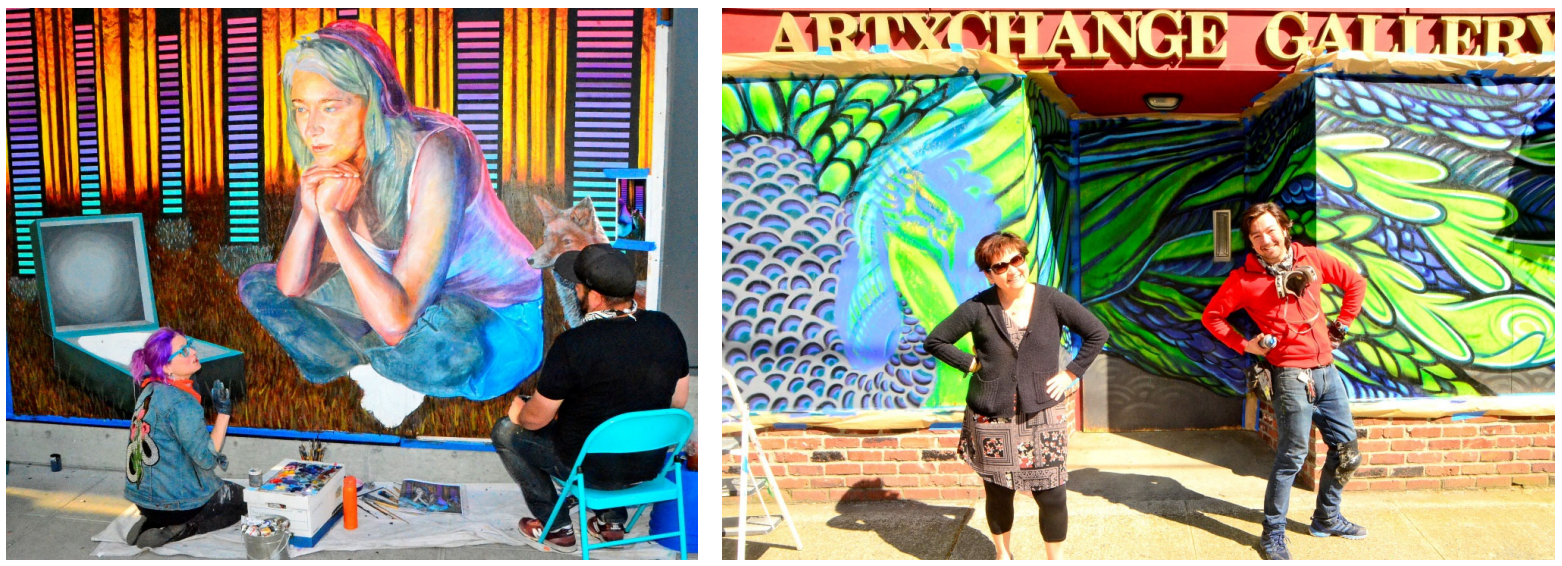

(left to right) Figure s. Artists Crystal Barbre, Casey Weldon and Zach Takasawa. Figure t. Artists Jonathan Fischer and Wakuda Studio.

Pictures by Catherine Anstett (2020).

The street scene largely consisted of artists doing their work, a few photographers and others watching them work. In Pioneer Square, there was a third group on the street those who had no other place to go.

Artist Sydney Pertl wrote: "When I was painting these, the outpouring of love and support was incredible! I made friends with many passers-by - photographers, dog walkers, and many currently experiencing homelessness. A special shout out to my new friend 'Papa,' who made me smile every time he passed me to and from the shelter. The coolest thing that happened were the two surprising thank yous I received on the same day - one from a USPS mailman hand delivering packages and the other from an ambulance driver who stopped in the middle of the street to yell thank you out of his window. 
Artists in the Streets. Seattle Murals in the Time of COVID-19
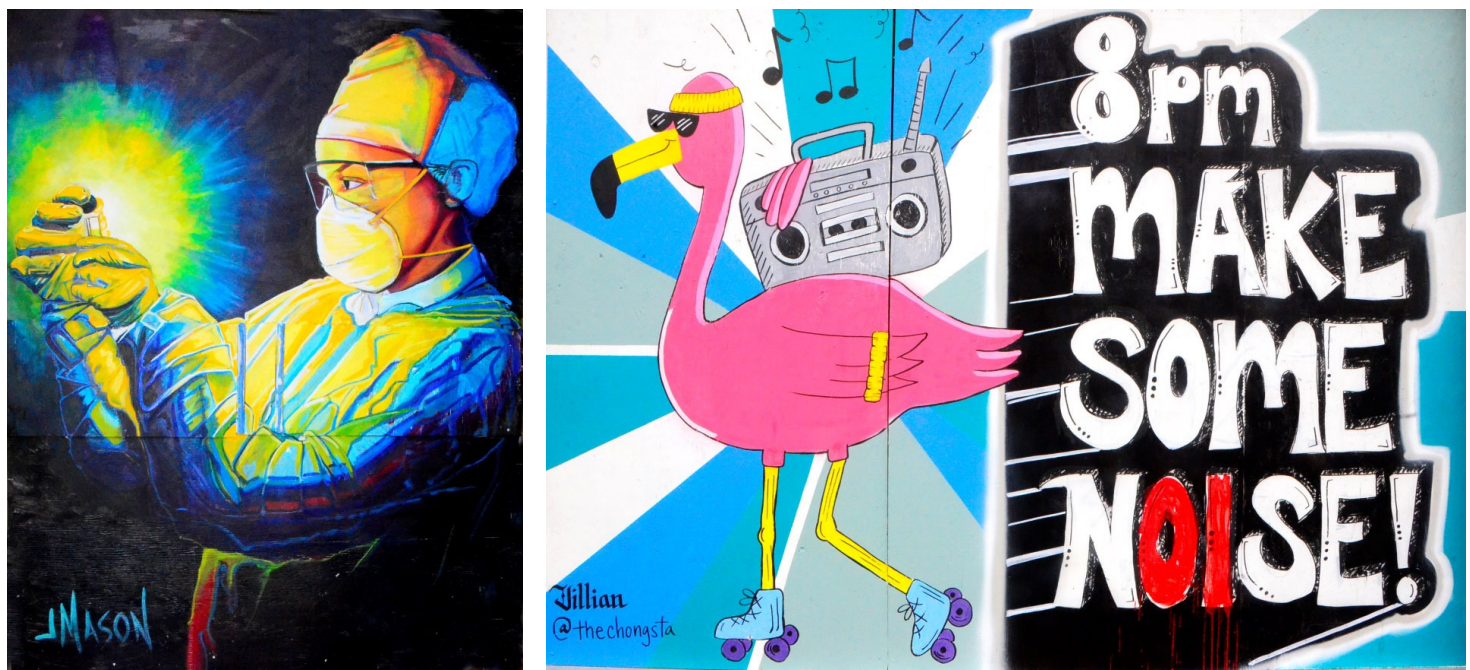

(left to right) Figure u. Artist Jay Mason. Figure v. Artist Jillian Chong. Pictures by Catherine Anstett (2020)

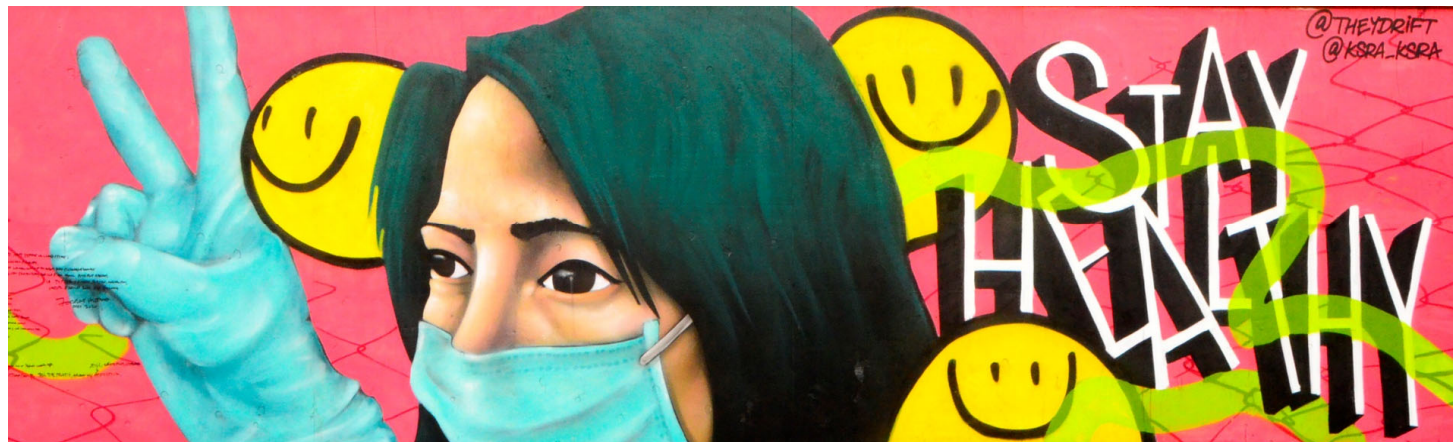

Figure w. Artist They Drift and Ksra. Picture by Catherine Anstett (2020).

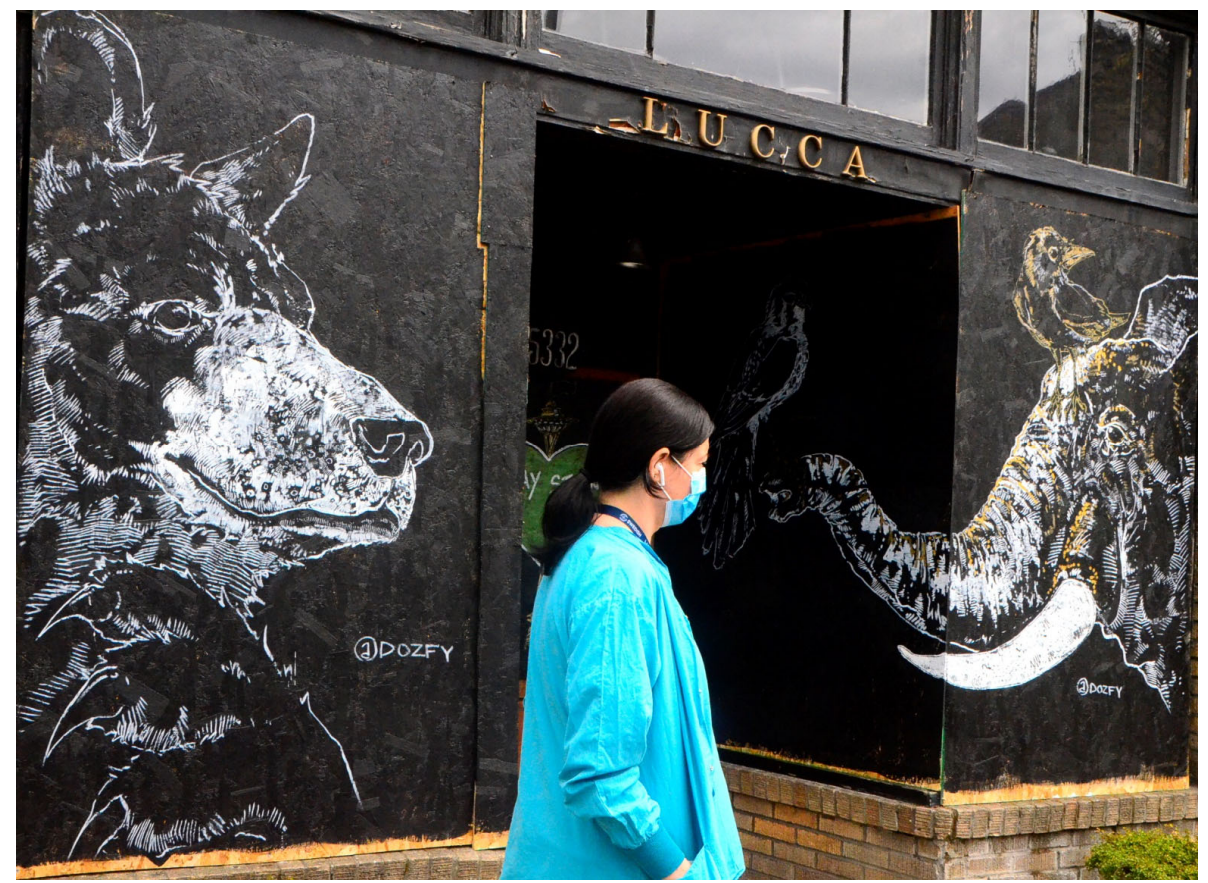

Figure w. Artist They Drift and Ksra. Picture by Catherine Anstett (2020).

The Journal of Public Space, 5(3), 2020 | ISSN 2206-9658 | 263 City Space Architecture / UN-Habitat 
"The most eye-opening thing I learned while painting in the same place every day was just how much Pearl Jam and Eddie Vedder have been doing for the homeless community here in Pioneer Square (my home). I heard so many stories about Eddie Vedder - signing Real Change newspapers, paying a man who was washing storefront windows to try to make a few dollars, pulling guitar picks out of his pocket to give to a man playing on the corner, and even tossing a football with a man in the middle of South Washington street (where my mural is located). It was inspiring how every single action I heard about became a monument to genuine humanity.
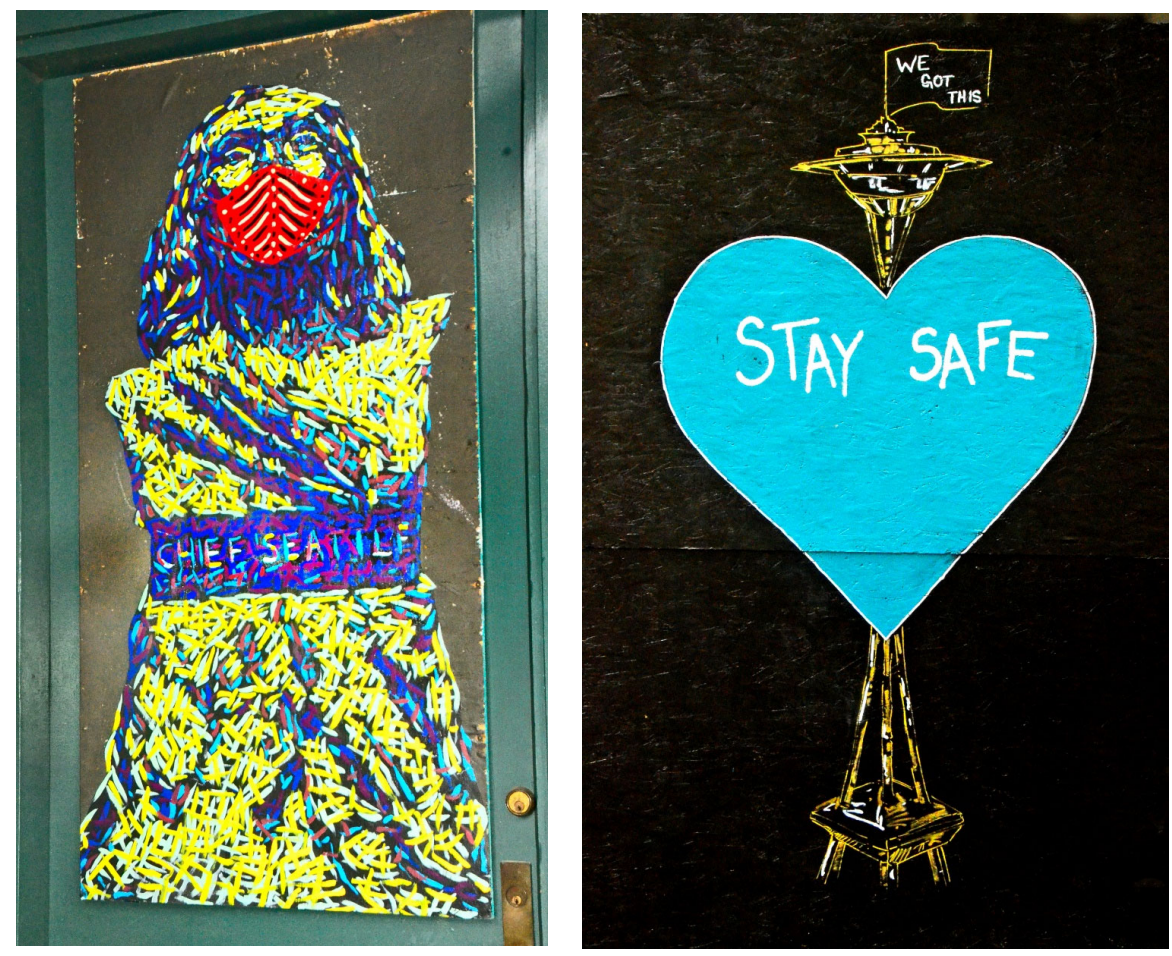

(left to right) Figure y. Artist Baso Fibonacci. Figure z. Artist Dozfy. Pictures by Catherine Anstett (2020).

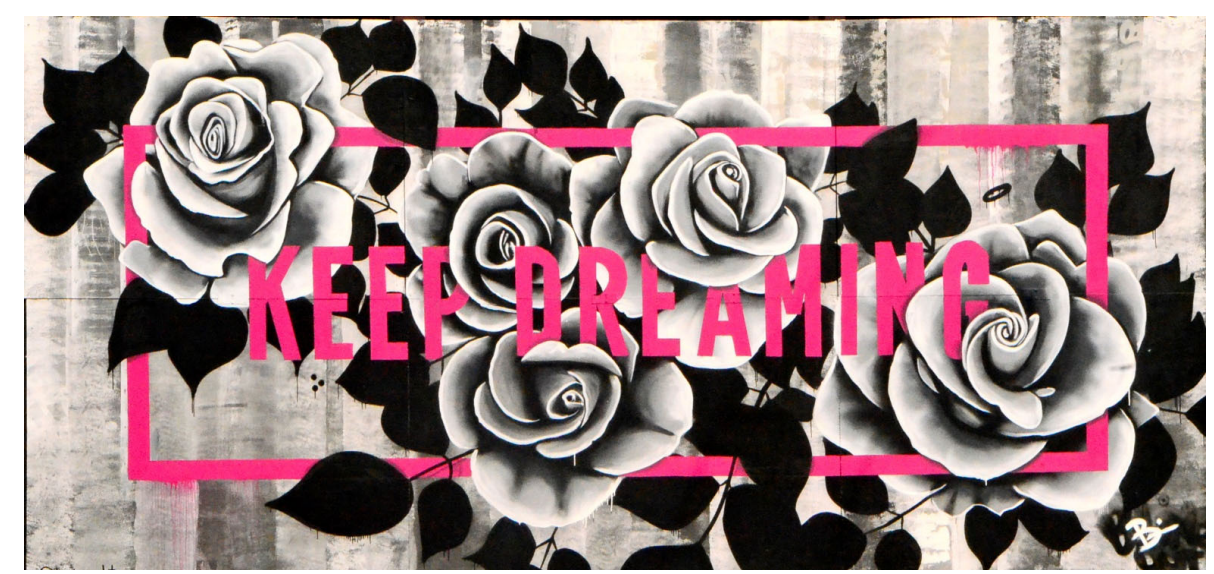

Figure za. Artist B Line Dot. Picture by Catherine Anstett (2020). 
"I hope my murals gave even a fraction of that much hope and inspiration, but it turns out that just hanging out with people (yes, six feet apart for now) means so much more." 5 (Figure zd)

The Seattle Office for Arts and Culture said, "Throughout this crisis, we have seen community come together and hold each other up like never before. We have watched organic movements take hold that are devoted to supporting those in need financially, emotionally, spiritually, and creatively. We have come together to feed one another, protect one another, entertain one another, and sustain one another through this dark and uncertain time." 6

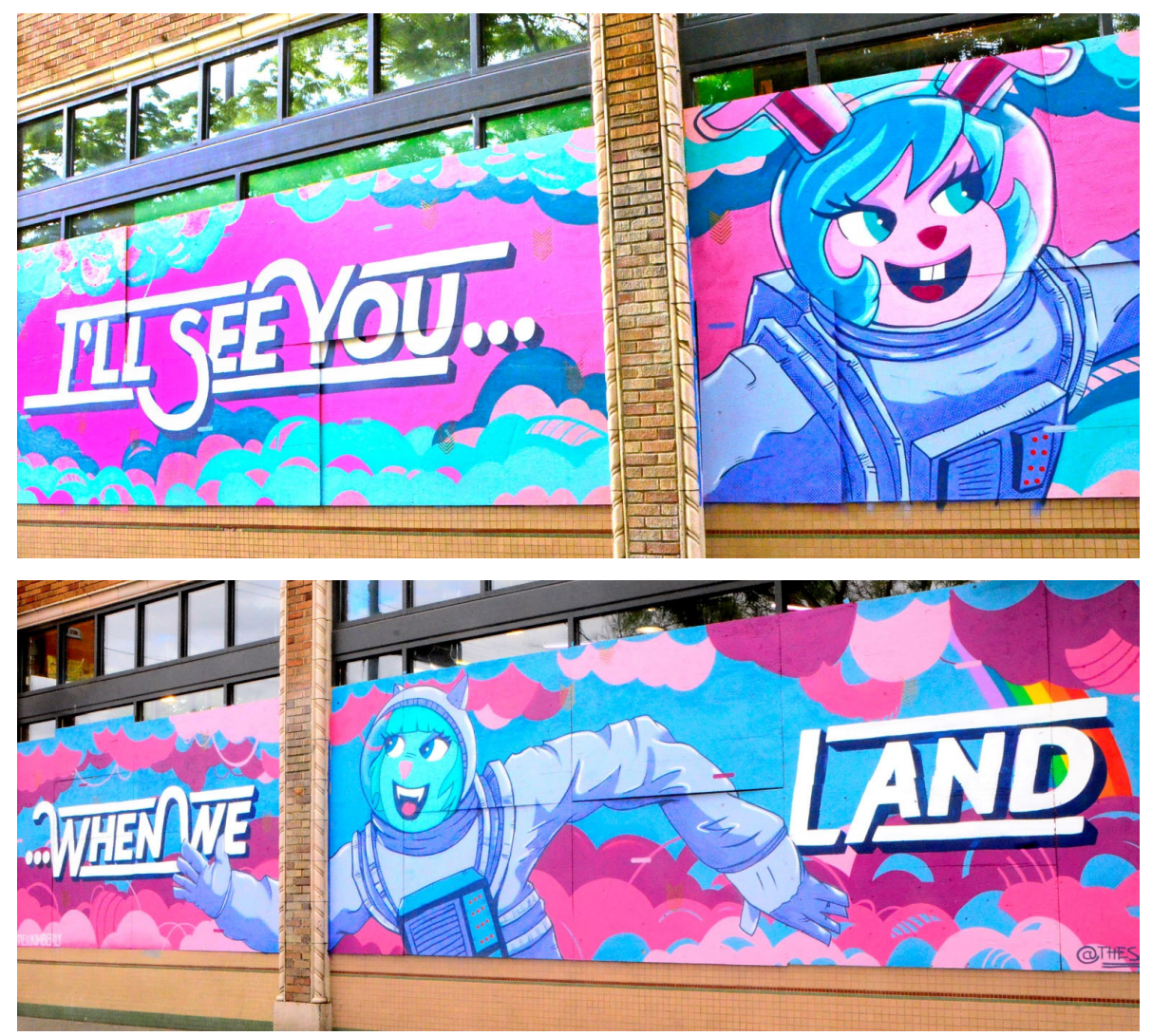

(top to down) Figure zb. Artist Sam Trout, text: Kimberly Tieu. Figure zc. Artist Sam Trout, text: Kimberly Tieu

Pictures by Catherine Anstett (2020).

The murals were an important part of this effort, for the artists, businesses, and the larger community. It has been a once-in-a-lifetime experience. So far. It's not clear if the stores and restaurants will need to close again if there is a second wave of the virus later this year. It's not clear when the plywood murals will come down, though in late May that was already happening in some areas.

A book documenting the murals is in the works, with expected publication in June. Historical societies are collecting photos and stories. The murals may be exhibited or auctioned. Some will be displayed in the stores and restaurants that hosted them. At least one documentary is underway. But the actual experience of this living art gallery in the streets, throughout the city, will be hard to replicate. And no one wants a repeat of the COVID- 19 health risk that occasioned it. 
As the artist B Line Dot said, "Art marks moments... this is a moment." 7

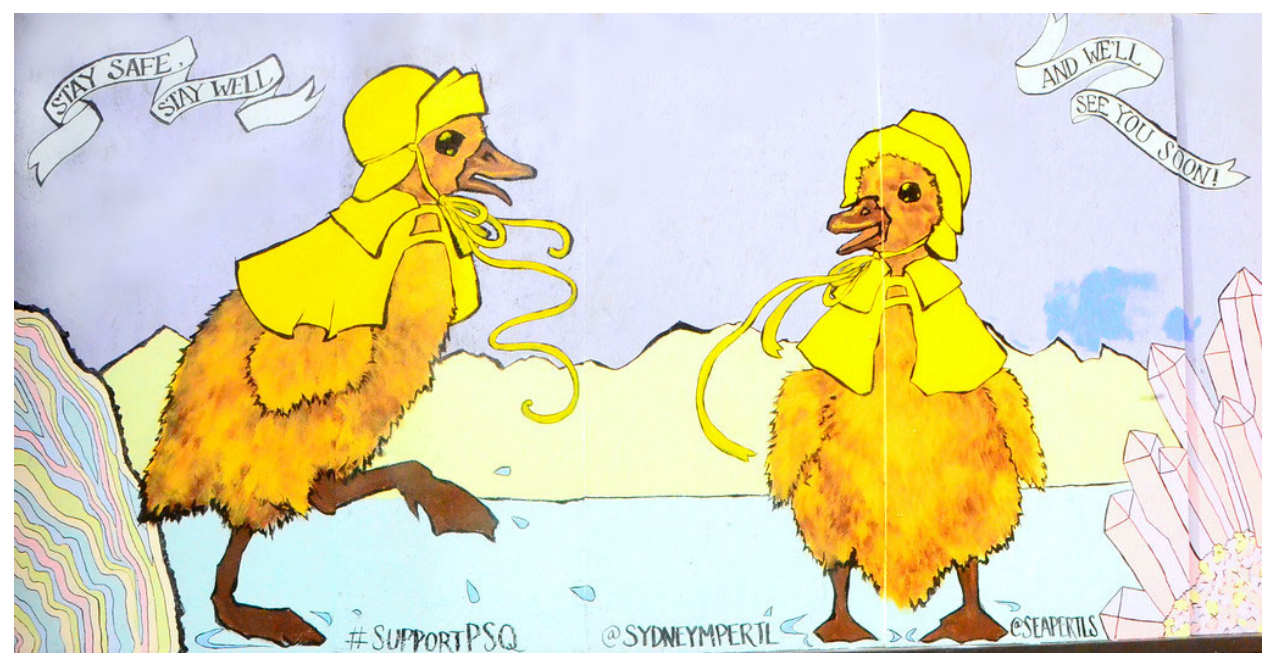

Figure w. Artist Sydney Pertl. Picture by Catherine Anstett (2020).

\section{References}

Art Beat Blog, Seattle Office of Arts and Culture, Erika Lindsay, April 9, 2020 / https://artbeat.seattle.gov/2020/04/09/seattletogether-shines-a-light-on-communityconnections/

Artist B Line Dot, Facebook, May I, 2020 / https://www.facebook.com/blinedot B Line Dot, Facebook, May 4, 2020 / https://www.facebook.com/blinedot Jay Mason, Facebook, April 30, 2020 / https:/www.facebook.com/JayMasonArt KING 5 NEWS, January 2019 / https://www.king5.com/article/news/seattle-still-the-cranecapital-of-the-us/281-7f6d9c57-e6dd-4eef-986f-25af5361952a

Sam Trout, Facebook, April 25, 2020 / https://www.facebook.com/sam.trout Sydney Pertl, Facebook, April 23, 2020 / https://www.facebook.com/sydneympertl 